\title{
MORPHOLOGICAL FINDINGS IN THE CRANIAL MESENTERIC ARTERY OF HORSES WITH VERMINOUS ARTERITIS
}

\author{
MARINKOVIĆ D*, ALEKSIĆ-KOVAČEVIĆ SANJA*, KRSTIĆ V** and KNEŽEVIĆ MILIJANA*
} ${ }^{*}$ Department of Pathology, ${ }^{*}$ Department of Equine, small animal, poultry and wild animal diseases,
University of Belgrade, Faculty of Veterinary Medicine, Belgrade

(Received 19. December 2008)

Cranial mesenteric arteries of 18 sacrificed necropsied horses of both sexes and different age groups were described in this paper. After macroscopic examination tissue samples for pathohistological examinations were routinely processed and stained with hematoxylin eosine (HE), Weigert van Gieson and Periodic-Acid-Schiff (PAS) staining.

Immunohistochemical staining was performed on selected sections using avidin-biotin-peroxidase complex technique for ásmooth muscle actin ( $\alpha-S M A)$.

Enlarged, thickened cranial mesenteric arteries with a hardelastic consistency and narrowed lumen, were macroscopically evident in all examined sick horses. Live larvae of Strongylus vulgaris, situated free in the lumen, or attached to the intima of the blood vessel or incorporated in the thrombus were noted macroscopically in $37.5 \%$ examined sick horses. Inflammatory and fibrous changes were noticed and were present in the intima, media and adventitia of the blood vessel. The inflammatory infiltrate in the intima of the cranial mesenteric artery consisted of eosinophils, macrophages, plasma cells, lymphocytes and rare multinucleated giant cells and was situated mostly close to the Strongylus vulgaris larvae. Beside inflammatory changes, intimal fibrosis and extension, characterized by increased proliferation of $\alpha$-SMA positive cells, was notable. Lesions of the internal elastic lamina consequently led to an inflammatory and fibrotic reaction in the tunica media. Fibrosis of the media characterized by the presence of connective tissue cells and fibers, as well as smoothmuscle cells, was present in 93.75\% examined sick horses. Inflammation and fibrosis were mildest in the adventitia. Lesions of vasa vasorum were present in $81.25 \%$ examined sick animals were characterized by fibrosis, obliteration, perivascular cellular infiltration, mostly with eosinophils and findings of intimal bodies. All described changes are characteristic for cranial mesenteric artery verminous arteritis.

Key words: horse, cranial mesenteric artery, morphological changes, verminous arteritis 


\section{INTRODUCTION}

Strongylus vulgaris is one of the most common parasites of horses and other equides. While adult forms of this parasite live in the large intestine of horses and usually do not cause health problems, larval forms spend part of their life cycle in the cranial mesenteric artery and its branches where they cause inflammation (Bowman et al., 1999; Van Vleet and Ferrans, 2007; Maxie and Robinson, 2007). These inflammatory changes have a bad influence on the general health condition of infected horses and reduce the working capacity of these animals. Beside, these changes represent the most important factor in the development of thromboembolic colics. About $10 \%$ of all deaths of horses are due to thromboembolic colics which are closely connected to infections with Strongylus vulgaris (Coffman and Carlson, 1971).

Morphological examinations would contribute to better understanding of lethal causes, ethiopathogenesis of verminous arteritis of the cranial mesenteric artery in dead and sacrificed horses, as well as adequate control, therapy and prevention of this disease.

Verminous arteritis (thrombotic arteritis, arteriitis thromboticans) is an inflammation of the cranial mesenteric artery in horses caused with Strongylus vulgaris larvae. It is characterized by endothelial lesions, creation of thromb masses in the lumen of the artery, as well as narrowing of its lumen. The intima and media of the blood vessel are infiltrated with inflammatory cells, but the arterial wall can also be thinned with a widened lumen of the blood vessel - aneurism formation. This disease is present in all parts of the world in domesticated and wild equids of all breeds and age, but it is more frequent in younger horses. Older horses can also be infected, especially if their immune system is weakened and if there are good conditions for infection (Lyons et al., 1981; Lyons et al., 1985; Lyons et al., 1987; Matthee et al., 2000; De Lay, 2001; Wambwa, 2004; Lyons et al., 2006).

The macroscopic appearance of the cranial mesenteric artery and its branches with verminous arteritis is characterized by enlargement and thickening with hard-elastic, fibrous, consistency, with thrombotic changes (Coffman and Carlson, 1971; Duncan, 1973; Duncan and Pirie, 1975; White et al., 1983; Slocombe and McCraw, 1984; Slocombe et al., 1987; Klei et al., 1990; Radostis et al., 1994; Rooney and Robertson, 1996; Van Vleet and Ferrans, 2007). Live larvae of Strongylus vulgaris, often incorporated in the thrombus, or attached to the intima of the blood vessels are evident (Rooney, 1970; Duncan and Pirie, 1975; White et al., 1983; Slocombe et al., 1987; Van Vleet and Ferrans, 2007). The arterial wall is thickened (Radostis et al., 1994; Maxie and Robinson, 2007). According to one group of authors (Duncan, 1974; Maxie and Robinson, 2007) aneurisms are not a part of verminous arteritis and the common finding within this disease is thickening of the arterial wall. Contrary to them some authors are of the opinion that aneurisms are a regular finding within verminous arteritis (Forenbacher, 1983; Klei et al., 1990), while there are some authors which are of the opinion that aneurisms can be a finding, but not on a regular bases (Rooney and Robertson, 1996). Beside the mentioned changes contortious fibrinous and 
Acta Veterinaria (Beograd), Vol. 59. No. 2-3, 231-241, 2009.

Marinković $\mathrm{D}$ et al.: Morphological findings in the cranial

mesenteric artery of horses with verminous arteritis

fibrous plaques in the arterial intima or periarterially can also be noted (Klei et al., 1982a; Maxie and Robinson, 2007). Also a large amount of fibrous tissue is present periarterially (Slocombe and McCraw, 1984). In some cases spontaneous ruptures of the wall of the cranial mesenteric artery can occur (Coffman and Carlson, 1971; Radostis et al., 1994).

Pathohistological findings are characteristic. Live larvae and a thrombus which is formed as a result of lesions of the arterial endothelium caused by larval migration, are present in the lumen of the blood vessel. Large amounts of blood and necrotic detritus placed in the space between the tunica intima and tunica media, together with the thrombus can partially or totally occlude the lumen of the artery (Coffman and Carlson, 1971; Maxie and Physick-Sheard, 1985; Morgan et al., 1991; Radostis et al., 1994; Kumar et al., 2003). Toxic substances and mediators secreted by Strongylus vulgaris larvae contribute to the development of inflammatory reactions in the subendothelial layer of the blood vessel. Strongylus vulgaris larvae destruct the endothelium in large blood vessels, migrate through the subendothelial connective tissue or sometimes are closely attached to the internal elastic lamina, while its caudal part, covered by a thin layer of fibrin, lies in the lumen of the artery. Lesions of the internal elastic lamina occur as a result of mechanic effects of the larvae, inflammatory mediators released by larvae and inflammatory cells, macrophage elastases, and local hypertension which is a result of thrombosis and/or intimal fibrosis (Morgan et al., 1991; Rooney and Robertson, 1996). Intimal fibrosis occurs as a result of proliferation of connective tissue cells and fibers, as well as smooth muscle cells (Coffman and Carlson, 1971; Duncan and Pirie, 1975; Maxie and Physick-Sheard, 1985; Klei et al., 1990; Morgan et al., 1990; Morgan et al., 1991; Rooney and Robertson, 1996; Maxie and Robinson, 2007). Lesions of the tunica media are similar, but less frequent to those mentioned in intimal fibroses, and the cause for the onset of fibrosis of the tunica media is the lesion of the internal elastic lamina. Proliferation of smooth muscle cells in the media occurs under the influence of the factors produced by Strongylus vulgaris larvae, and other factors which originate from the platalets. Hypoxia and PDGF can alone stimulate smooth muscle cells, which are due to proliferation present in a large number to produce collagen (Morgan et al., 1989; Morgan and Van Houten, 1990; Morgan et al., 1991). Lesions of the adventitia are present mostly in the chronic form of the disease and are characterized by the presence of thrombi in the vasa vasorum, and later the development of fibrosis. Fibroblasts are the main source of collagen in the adventitia, and fibrosis occurs due to hypoxia and poor oxygenation, and it is especially expressed on the vasa vasorum (Morgan and Van Houten, 1990; Morgan et al., 1991). In the intima of vasa vasorum small basophilic structures which prominate towards the lumen, and are referred as intimal or asteroid bodies, are often seen in all age categories of horses except very young foals and fetuses. Due to this some authors are of the opinion that these structures are directly correlated to Strongylus vulgaris larvae migration (Bollinger, 1869; Rooney and Robertson, 1996), while other authors state that this is not a case (Maxie and Robinson, 2007). 


\section{MATERIALS AND METHODS}

Cranial mesenteric arteries of 16 necropsied and sacrificed horses of both sexes ( 8 male and 8 female) and age were examined in this paper. Arteries of 2 clinically healthy horses ( 1 male, 1 female) were taken as the control. Arteries were examined macroscopically, changes were described and photodocumented and tissue samples for pathohistological examinations were taken. Samples of arteries without changes were also examined and were taken as control samples.

Tissue samples were fixed in $10 \%$ buffered formalin during 24-48 hours. After standard processing in an automated tissue processor the samples were embedded in paraffin blocks. The $3-5 \mu \mathrm{m}$ thick paraffin sections were stained with hematoxylin eosine (HE), Weigert van Gieson and Periodic-Acid-Schiff (PAS) staining.

Immunohistologic investigations on selected sections of cranial mesenteric arteries were performed with murine monoclonal antibodies specific for $\alpha$-smooth muscle actin ( $\alpha$-SMA, DAKO). Briefly, after incubation with primary antibodies ( $\alpha-$ SMA 1:100, high temperature demasking technique in citrate buffer, $\mathrm{pH}=6$ ) the antigen-antibody complex was visualized using the avidin-biotin-peroxidase complex technique (LSAB 2, DAKO) and diaminobenzidine (DAB+, DAKO). Tissue sections were counterstained with Mayers hematoxylin. Negative controls consisted of sections incubated with mouse normal serum instead of primary antibody.

\section{RESULTS}

\section{Macroscopic findings}

Macroscopic examination revealed that cranial mesenteric arteries of all 16 examined sick horses were enlarged, thickened with a hard-elastic consistency (Fig. 1.a). A thrombus was noted in the arterial lumen in one third of examined sick

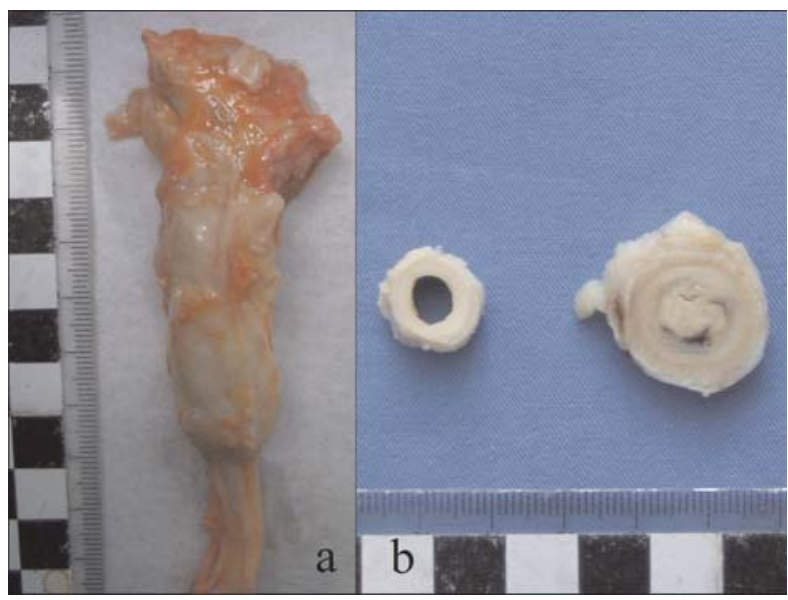

Figure 1 a. Macroscopic appearance of the enlarged, thickened cranial mesenteric artery; b. Normal artery (left) and artery with thickened wall and narrowed lumen with thrombus (right) 
horses (Fig. 1.b; Fig. 2.). Live larvae of Strongylus vulgaris were noted, either free in the lumen of the artery, or incorporated in the thrombus (Fig 2.b). The arterial wall was thickened and the lumen was considerably narrowed in 16 examined affected horses (Fig. 1.b; Fig. 2.). The presence of contorted fibrinous and fibrous tracks and plaques situated in the arterial intima and periarterially was evident in the majority of sick horses.

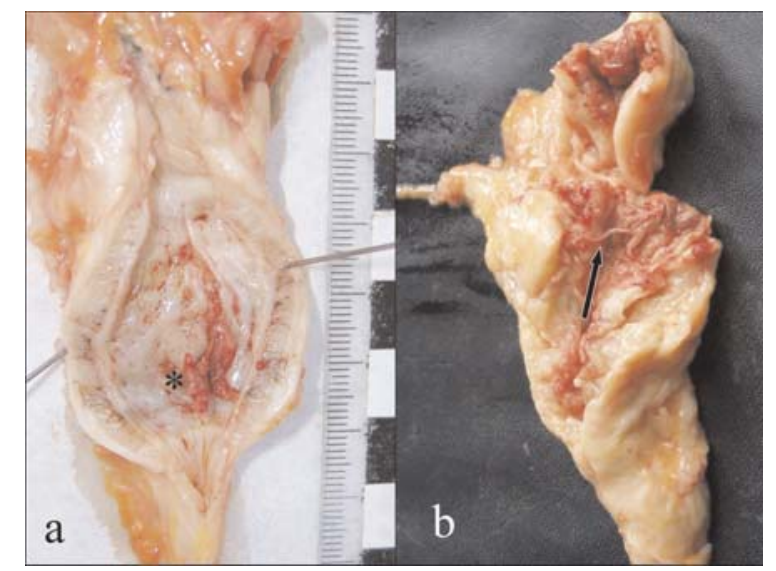

Figure $2 \mathrm{a}$. Thickened arterial wall with a thrombus in the lumen; b. Live larvae of Strongylus vulgaris in the arterial lumen

\section{Pathohistologic finding}

Pathohistological examination revealed Strongylus vulgaris larvae in the cranial mesenteric arteries of $13(81.25 \%)$ animals. Live larvae, situated in the arterial lumen, in the thrombus or in the arterial intima were recorded in $4(25 \%)$, while dead, fragmented, degenerated and calcified larvae were recorded in 9 $(56.25 \%)$ cases. The intima of the cranial mesenteric artery was infiltrated with eosinophils, macrophages, plasma cells, lymphocytes and rare multinucleated giant cells. (Fig. 3 a, b). Intimal fibrosis, noted in all examined sick animals, was characterized by proliferation of connective tissue cells and fibers, as well as smooth-muscle cells. All animals also had a clear extension of the intima. Lesions of the internal elastic lamina were expressed mostly in the form of its discontinuity, accumulation of mononuclear cells in its surroundings and sometimes separation of the intima and media.

Inflammatory changes of the media of the cranial mesenteric artery characterized by infiltration with eosinophils, macrophages, plasma cells, lymphocytes and rare multinucleated giant cells were seen in 14 (87.5\%) examined sick horses. Fibrosis of the media characterized by the presence of connective tissue cells and fibers, as well as smooth-muscle cells was present in $15(93.75 \%)$, and degeneration and necrosis of smooth-muscle cells was noted in $11(68.75 \%)$ examined sick horses. Dead, fragmented, degenerated and calcified larvae were noted in the media of the cranial mesenteric artery of $5(31.25 \%)$ examined sick animals. Siderocytes situated in the media were present in the same percentage. 


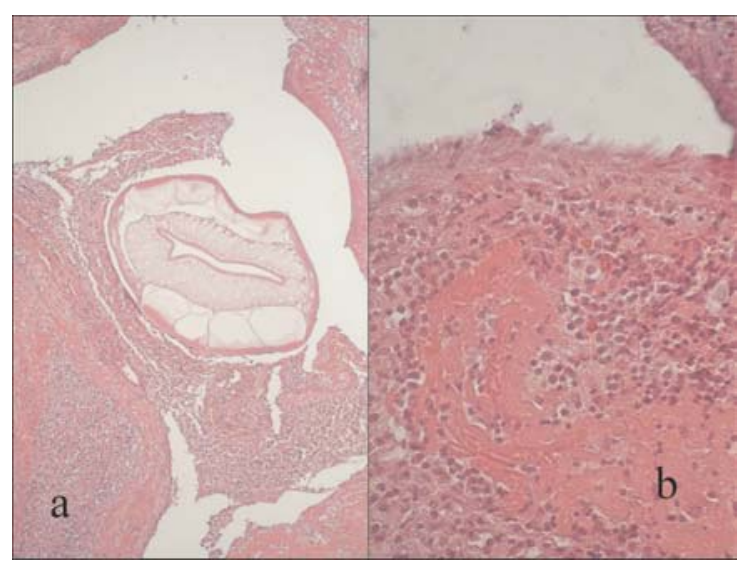

Figure 3 a. Larvae of Strongylus vulgaris-a free in the arterial lumen (HE, x 100); b. Cellular infiltration of the intima (HE, x 200)

Adventitial fibrosis characterized with proliferation of connective tissue cells and smooth-muscle cells was noted in $12(75 \%)$ examined sick horses. Lesions of vasa vasorum were present in $13(81.25 \%)$ examined sick animals and were characterized by fibrosis, obliteration, perivascular cellular infiltration, mostly with eosinophil granulocytes and findings of intimal bodies.

\section{Immunohistochemical findings}

Strong immunoreactivity for $\alpha$ SMA ( $\alpha$ smooth muscle actin) was noted immunohistochemically in smooth muscle cells, as well as in myofibroblasts of tunica intima, tunica media and vasa vasorum in the tunica adventitia of cranial mesenteric arteries with prominent fibrosis (Fig. 4).

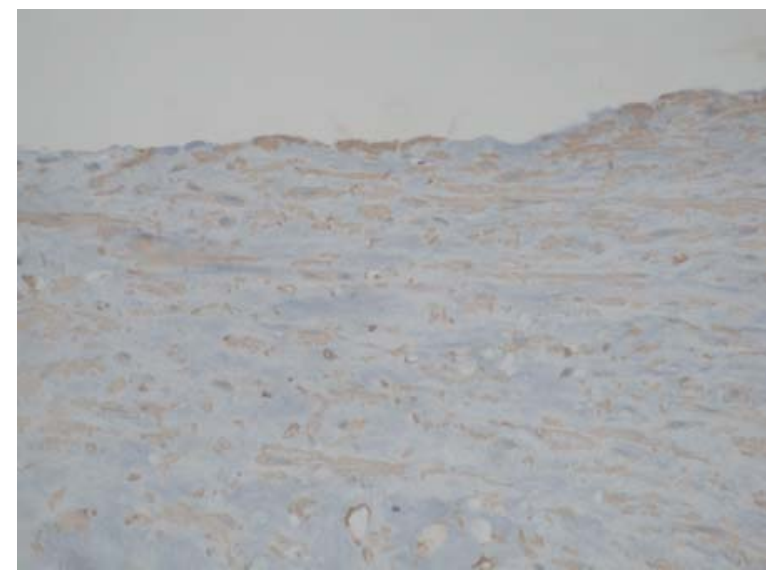

Figure 4. Strong immunoreactivity for $\alpha$-smooth muscle actin in the tunica intima of cranial mesenteric artery ( $\alpha$-SMA, counterstained with hematoxylin $x 400)$ 
Acta Veterinaria (Beograd), Vol. 59. No. 2-3, 231-241, 2009.

Marinković D et al.: Morphological findings in the cranial

\section{DISCUSSION}

Enlarged, thickened cranial mesenteric arteries with hard-elastic, fibrous consistency were recored in all examined sick horses. These findings are consistent with the macroscopic description of verminous arteritis of the cranial mesenteric artery and its branches by a number of authors (Duncan and Pirie, 1975; Slocombe and McCraw, 1984; Slocombe et al., 1987; Klei et al., 1990; Radostis et al., 1994; Maxie and Robinson, 2007; Van Vleet and Ferrans, 2007). A thrombus, which narrows the arterial lumen, was noted in $37.5 \%$ examined sick horses as reported by many authors (Rooney, 1970; Duncan, 1973; Duncan and Pirie, 1975; Pauli et al., 1975; White et al., 1983; Slocombe et al., 1987; Klei et al., 1990; Radostis et al., 1994; Rooney and Robertson, 1996; Van Vleet and Ferrans, 2007). Migration of larval stages of Strongylus vulgaris plays the most important role in the pathogenesis of verminous arteritis of the cranial mesenteric artery and formation of thrombi in the lumen of this blood vessel. In the material processed in this investigation live larvae of Strongylus vulgaris were noted macroscopically in $37.5 \%$ examined sick horses, and were situated free in the lumen, or attached to the intima of the blood vessel or even incorporated in the thrombus (Rooney, 1970; Duncan and Pirie, 1975; White et al., 1983; Slocombe et al., 1987; Van Vleet and Ferrans, 2007). During migration larval stages of Strongylus vulgaris make lesions on the endothelium of arteries which represent the most important factor of Virchofs' triad of thrombogenesis. Mechanic lesions of endothelium lead to the denudation of subendothelial collagen and its direct contact with blood. The exposure of subendothelial collagen and other platelet activators to the circulating blood leads to platelet adhesion and release of tissue coagulation factors. Damaged endothelium can produce a large amount of procoagulating factors (platelet adhesion molecules, tissue factors, inhibitor of plasminogen activators, platelet aggregation factor (PAF) and other) and small amounts of anticoagulating effectors (thrombomodulin, activators of plasminogen (AP), prostaglandin $\mathrm{PGI}_{2}$ and other). All this consequently leads to platelet adhesion and shape changes, their secretion and aggregation with the formation of a thrombus which can partially or totally obliterate the blood vessel lumen. However, aneurisms of the cranial mesenteric artery were not noticed in the material processed in this investigation. The arterial wall was thickened in variable percentages in all examined horses, which is consistent with many authors (Duncan, 1974; Radostis et al., 1994; Maxie and Robinson, 2007) which have the opinion that an aneurism is not a change related to verminous arteritis of the cranial mesenteric artery. Contrary to them other authors state that aneurisms are a regular change related to this disease (Forenbacher, 1983; Klei et al., 1990; Rooney and Robertson, 1996).

According to literature data development of verminous arteritis goes through three phases: acute phase of inflammation, chronic phase of inflammation and chronic active phase of inflammation (Morgan et al., 1991; Rooney and Robertson, 1996; Maxie and Robinson, 2007; Van Vleet and Ferrans, 2007). 
Interesting is the chronic active phase of the disease, which is characterized by locally extensive necrosis of the intima of the blood vessel with edema, fibrin deposits and accumulation of eosinophils, neutrophils, macrophages, plasma cells and lymphocytes, as well as lesions of internal elastic lamina (Duncan and Pirie, 1975; Slocombe et al., 1987; Morgan et al., 1991; Rooney and Robertson, 1996; Maxie and Robinson, 2007). In the tunica media inflammatory reactions, necrosis of smooth-muscle cells with the presence or absence of degenerated larvae, as well as low to medium grade fibrosis can be noted. In arteries which have thin walls and a dilated lumen sometimes large amounts of collagen fibers and small numbers of smooth muscle cells can be noted in the media of these blood vessels (Slocombe et al., 1987; Morgan et al., 1990; Morgan et al., 1991). In this phase of the disease in vasa vasorum in tunica adventitia changes are rare and when present are expressed in the form of fibrosis (Morgan et al., 1991).

Intimal fibrosis and extension was characterized by proliferation of connective tissue cells and fibers, as well as smooth-muscle cells (Coffman and Carlson, 1971; Duncan and Pirie, 1975; Maxie and Physick-Sheard, 1985; Klei et al., 1990; Morgan et al., 1991; Rooney and Robertson, 1996). Fibrosis of the media characterized by the presence of connective tissue cells and fibers, as well as smooth-muscle cells, present in $93.75 \%$ examined sick horses was reported by other authors, as well (Slocombe et al., 1987; Morgan et al., 1990; Morgan and Van Houten, 1990; Morgan et al., 1991). Adventitial fibrosis characterized by proliferation of connective tissue cells and smooth-muscle cells was noted in $75 \%$ examined sick horses as reported by Morgan et al. (1991). Lesions of vasa vasorum were present in $81.25 \%$ examined sick animals were characterized with fibrosis, obliteration, perivascular cellular infiltration, mostly with eosinophils and findings of intimal bodies which, according to literature (Bollinger, 1869; Rooney and Robertson, 1996), are often seen in all age categories of horses except very young foals and fetuses. Because of this fact authors have the opinion that these structures are directly correlated to Strongylus vulgaris larvae migration, while other authors state that they are not correlated to the migration of this parasite (Maxie and Robinson, 2007).

ACKNOWLEDGEMENTS

This work was supported by grant 156010 from the Ministry of Science and Technological Development of the Republic of Serbia

\author{
Address for correspondence: \\ Mr Marinković Darko \\ Department of Pathology \\ University of Belgrade \\ Faculty of Veterinary Medicine \\ 11000 Belgrade \\ Bulevar oslobođenja 18 \\ Serbia \\ E-mail: darko@vet.bg.ac.rs
}




\section{REFERENCES}

1. Bollinger O, 1869, Uber eigentumliche Korperchen in den feinen Arterien des intestinaltraktus beim Pferde, Virchows Archiv 47, 89-95.

2. Coffman JR, Carlson KL, 1971, Verminous Arteritis in Horses, J Am Vet Med Assoc, 158, $1358-60$.

3. De Lay J, Peregrine AS, Parsons DA, 2001, Verminous arteritis in a 3-month-old thoroughbred foal, Can Vet J, 42, 289-91.

4. Dennis VA, Klei TR, Chapman MR, 1993, Generation and partial characterization of an eosinophil chemotactic cytokine produced by sensitized equine mononuclear cells stimulated with Strongylus vulgaris antigen, Vet Immunol Immunopathol, 37, 135-49.

5. Duncan JL, 1973, The life cycle, pathogenesis and epidemiology of Strongylus vulgaris in the horse, Equine Vet J, 5, 20-5.

6. Duncan JL, 1974, Strongylus vulgaris infection in horse, Vet Rec, 95, 34-7.

7. Duncan JL, Pirie HM, 1975, The pathogenesis of single experimental infections with Strongylus vulgaris in foals, Res Vet Sci, 18, 82-93.

8. Bowman DD, Lynn RC, Eberhard ML, Alcaraz A, 1999, Georgis Parasitology for veterinerians, eight edition, Saunders, 174-6.

9. Forenbacher S, 1983, Klinička patologija probave i mijene tvari domaćih životinja, svezak I/2, Jugoslovenska akademija znanosti i umjetnosti i Sveučilišna naklada Liber, Zagreb, 597-604.

10. Gardiner CH, Poyton SL, 1999, An atlas of metazoan parasites in animal tissues. Armed Forces institute of Pathology, American registry of Pathology, Washington DC, 23.

11. Klei TR, Torbert BJ, Ochoa R, Bello TR, 1982a, Morphologic and clinicopathologic changes following Strongylus vulgaris infections of immune and nonimmune ponies, Am J Vet Res, 43, 1300-7.

12. Klei TR, Òurk AM, McClure JR, Holmes RA, Dennis VA, Chapman MR, 1990, Effects of repeated Strongylus vulgaris inoculations and concurent ivermectin treatments on mesenteric arterial lesions in pony foals, Am J Vet Res, 51, 654-60.

13. Kumar V, Cotran R, Robbins SL, 2003, Haemodynamic disorders, thrombosis and shock. In Robbins Basic Pathology, seventh edition, Saunders, Philadelphia, 90-4.

14. Lyons ET, Drudge JH, Swerczek TW, Tolliver SC, Crowe MW, 1981, Prevalence of Strongylus vulgaris and Parascaris equorum in Kentucky Thoroughbreds at necropsy, J Am Vet Med Assoc, 179, 818-9.

15. Lyons ET, Tolliver SC, Drudge JH, Swerczek TW, Crowe MW, 1985, Prevalence of some internal parasites recovered at necropsy of Thoroughbreds born in 1982 in Kentucky, Am J Vet Res, 46, 679-83.

16. Lyons ET, Tolliver SC, Drudge JH, Swerczek TW, Crowe MW, 1987, Common internal parasites found in the stomach, large intestine, and cranial mesenteric artery of Thoroughbreds in Kentucky at necropsy (1985 to 1986), Am J Vet Res, 48, 268-73.

17. Lyons ET, Tolliver SC, Collins SS, 2006, Prevalence of large endoparasites at necropsy in horses infected with Population B small strongyles in a herd established in Kentucky in 1966, Parasitol Res, 99, 114-8.

18. Matthee S, Krecek RC, Milne SA, 2000, Prevalence and biodiversity of helminth parasites in donkeys from South Africa, J Parasitol, 86, 756-62.

19. Maxie MG, Physick-Sheard PW, 1985, Aortic-lliac Thrombosis in Horses, Vet Pathol, 22, 238-49.

20. Morgan SJ, Storts RW, Stromberg PC, Sowa BA, Lay JC, 1989, Preliminary investigations on the effects of a Strongylus vulgaris larval extract, mononuclear factors and platelet factors on equine smooth muscle cells in vitro, Vet Res Commun, 13, 479-89.

21. Morgan SJ, Van Houten DS, 1990, The ultrastructure of Strongylus vulgaris-mediated equine chronic mesenteric arteritis, Vet Res Commun, 14, 41-6.

22. Morgan SJ, Stromberg PC, Storts RW, Sowa BA, Lay JC, 1991, Histology and Morphhology of Strongylus vulgaris-mediated Equine Mesenteris Arteritis, J Comp Path, 104, 89-99. 
23. Pauli B, Althaus S, Von Tscharner C, 1975, Arterial repair after mechanical injury by migrating fourthstage larvae of Strongylus vulgaris in the horse (a light and electron microscopic study), Beitr Pathol, 155, 357-78.

24. Radostis OM, Blood DC, Gay CC, 1994, Veterinary medicine - A Textbook of the Disease of Cattle, Sheep, Pigs, Goats and Horses, 1241-6.

25. Maxie MG, Robinson WF, 2007, Cardiovascular system, In: Jubb K.V.F., Kennedy PC, Palmer N Pathology of Domestic Animals, fifth edition. vol. 3, editor Maxie MG, Saunders Elsevier, 89-91.

26. Rooney JR, Robertson JL, 1996, Equine Pathology, lowa State University Press, Ames, 75-6.

27. Rooney JR, 1970, Autopsy of the Horse. The Williams \& Wilkins Company, Baltimore, 95-6.

28. Slocombe JOD, McCraw BM, 1984, Evaluation of ivermectin against later fourth-stage Strongylus vulgaris in ponies at two and five weeks after treatment, Can J Comp Med, 48, 343-8.

29. Slocombe JOD, McCraw BM, Pennock PW, Ducharme N, Baird JD, 1987, Strongylus vulgaris in the tunica media of arteries of ponies and treatment with ivermectin, Can $J$ Vet Res, 51, 232-5.

30. Wambwa EN, Ogara WO, Mudakha D, 2004, A comparative study of gastrointestinal parasites betwen ranched and free ranging Burchell's zebra (Equus burchelli antiquorum) in Isolo district, Kenya, J Vet Sci, 5, 215-20.

31. White NA, Moore JN, Douglas M, 1983, SEM study of Strongylus vulgaris larva-induced arteritis in the pony, Equine Vet J, 15, 412-7.

32. Van Vleet JF, Ferrans VJ, 2007, Cardiovascular System, In: McGavin MD, Zachary JF: Pathologic basis of veterinary disease, fourth edition, Mosby Elsevier, St. Louis, 602-6.

\title{
MORFOLOŠKI NALAZ NA KRANIJALNIM MEZENTERIJALNIM ARTERIJAMA KONJA SA VERMINOZNIM ARTERITISOM
}

\author{
MARINKOVIĆ D, ALEKSIĆ-KOVAČEVIĆ SANJA, KRSTIĆ V i KNEŽEVIĆ MILIJANA
}

\section{SADRŽAJ}

$\mathrm{U}$ ovom radu su ispitane kranijalne mezeneterijalne arterije 18 obdukovanih žrtvovanih konja različitog pola i starosti. Arterije su makroskopski pregledane i uzimani su tkivni isečci za patohistološka ispitivanja. Materijal za histološka ispitivanja fiksiran je u $10 \%$ puferizovanom formalinu i posle uobičajene procedure ukalupljen u parafinske blokove. Patohistološki preparati bojeni su hematoksilinom i eozinom (HE), Vajgert van Gison metodom i PAS metodom. Odabrani isečci imunohistohemijski su bojeni avidin-biotin-peroksidaza tehnikom za $\alpha$-smooth muscle actin ( $\alpha-S M A)$.

Makroskopski, kranijalne mezenterijalne arterije svih ispitanih konja bile su uvećane, zadebljale, čvrsto-elastične konzistencije i suženog lumena. Zive larve Strongylus vulgaris slobodne u lumenu ili pričvršćene za intimu krvnog suda ili inkorporisane u trombnu masu uočene su makroskopski kod $37,5 \%$ obolelih konja.

Mikroskopski su uočene promene inflamatornog do fibroznog karaktera $i$ bile su zastupljene u intimi, mediji i adventiciji krvnog suda. Inflamatorni infiltrat u intimi su činili eozinofilni granulociti, makrofage, plazma ćelije, limfociti i višejedarne džinovske ćelije i ovaj infiltrat bio je prisutan uglavnom u blizini larve Strongylus vulgaris. Pored inflamatornih promena uočeno je zadebljavanje sa fi- 
Acta Veterinaria (Beograd), Vol. 59. No. 2-3, 231-241, 2009.

Marinković D et al.: Morphological findings in the cranial

mesenteric artery of horses with verminous arteritis

brozom intime koja se karakterisala proliferacijom vezivno-tkivnih ćelija i vlakana, kao i glatko-mišićnih ćelija. Lezije na unutrašnjoj elastičnoj lamini posledično su dovodile do inflamacije i fibroze tunike medije. Fibroza medije se karakterisala prisustvom vezivno-tkivnih ćelija i vlakana, kao i glatko-mišićnih ćelija i bila je prisutna kod 93,75\% obolelih konja. Inflamacija i fibroza su najslabije bile izražene u adventiciji, a lezije vasa vasorum su bile prisutne kod $81,25 \%$ pregledanih obolelih životinja i karakterisale su se fibrozom, obliteracijom, perivaskularnom ćelijskom infiltracijom, uglavnom sa eozinofilima, kao i nalazom intimalnih tela. Sve opisane promene su karakteristične za verminozni arteritis kranijalne mezenterijalne arterije. 